\title{
International Sales and Distribution Strategies
}

\begin{abstract}
Although all companies researched in this study show extensive international market involvement, the strategies, as well as patterns of involvement, differ substantially. These differences relate to the geographies of the company's first exports, as well as the legal forms that were adopted, ranging from agents and distributors to wholly owned subsidiaries. As shall be addressed, some of these differences have to do with the firms' size and resources.

There are, however, some general patterns common to most of the sample companies. First and foremost, all the firms began their exporting operations early on in their development. Second, a key role was played by the company founders who traveled extensively to develop their businesses.

The development of some of the older firms was often impeded by wars and considerable fluctuations in currency values. Although these events impacted larger firms too, their relative impact on the smaller SMEs was more pronounced and required considerable managerial and entrepreneurial ingenuity to overcome.
\end{abstract}

\section{Early Pioneers of International Expansion}

Sefar's founder Pierre Dufour, who started the firm in 1833, making it the oldest firm in the research sample, undertook his first business trip to the USA just 2 years later.

As early as 1835, Pierre A. Dufour made his first business trip to the United States and succeeded in winning customers there. At that time, a trip to America could still be described as a real adventure. The crossing by ship took almost thirty days and was not without danger. In 1839, Dufour made his second trip to the US. Because the demand for silk bag cloth was greatest in industrialized countries where large, modern mills operated, the US became an important market. At the end of the 19th Century, half of the production of Swiss silk gauze 
went to the US. Swiss silk gauze was more expensive than that from other countries but of superior quality due to a special weaving technique and experienced weavers. ${ }^{1}$

Although these documented early trips of Dufour were to the USA, it can be assumed that he also traveled within Europe for business. As the company grew, and since international customers accounted for the largest part of its sales, management undertook the next big step and created a more permanent presence in the USA, followed by other operations in France.

In 1900, Dufour \& Co. founded its first subsidiary in New York. When the French producers of silk gauzes began to threaten the Swiss with their cheaper products, the Schweiz. Seidengauzefabrik AG Thal, in consultation with the its Zurich sister company, went on the offensive. In 1911, it established a weaving plant in Panissières, France, headed by Hermann Tobler. Later, other rival companies were bought out. In 1929, the subsidiaries of SST and SSZ in the North American market merged into a stock company under the name Tobler, Ernst \& Traber, Inc. Because of the reliance on imports and exports, both World Wars hit the company hard, but it managed to recover both times. ${ }^{2}$

The international expansion of Felchlin was partially affected by its traveling owner, although these developments did not always take the form of a deliberate strategy.

Entry into Japan came about in an ad-hoc manner. As part of his extensive travels, Max Felchlin, Jr., visited Japan in the 1970s. Given his talent for writing, he authored articles in the Neue Zürcher Zeitung (NZZ) about Japanese food and nutrition. Siber Hegner, a large Swiss exporting company with a major presence in Japan, at that time was looking for a hazelnut bakery filling to sell in Japan, so Felchlin was contacted and business developed. A Felchlin Club was established where Japanese traditional confiseurs could learn about Western style confiserie. As a result, Felchlin was present very early during the rise of the Japanese confiserie and pastry scene that today had eclipsed those of Europe and France and was now recognized as leading worldwide. ${ }^{3}$

Felchlin's entry into the US market came about as a result of a contact from a potential US customer with the firm and was unrelated to Max Felchlin Jr.'s extensive travels to the USA.

Bakery fillings, Felchlin's main product for decades, were hard to export as moisture problems posed packaging challenges. As it turned out, "the US came to Felchlin": A young chef acquainted with many Swiss and Europe-trained chefs in the US, let the company know that "we could sell European raw materials to the US market." An importer was appointed and, step by step, the business expanded. ${ }^{4}$

\footnotetext{
${ }^{1}$ Adapted from Sefar company profile.

${ }^{2}$ Ibid.

${ }^{3}$ Adapted from Max Felchlin company profile.

${ }^{4}$ Ibid.
} 
Entrepreneurs at other companies were also actively engaged in opening up markets, first in Europe and later overseas. Most of their trips took place after WWII and were often undertaken by car. Fernand Plumettaz traveled extensively to France to visit wine growers and campaign for his "Plumett" branded equipment. At Ricola, founder Emil Richterich, and later his son Hans-Peter, made frequent trips abroad to visit trade fairs and recruit potential distribution partners. At Felco, founder Felix Flisch personally traveled to agricultural centers in France, Germany, and the Benelux countries to demonstrate his tools.

Another pioneer traveling personally was Urs Baumann who took over Lantal from his father in 1964. With a passion for the aviation industry, he restructured the weaving company with special attention to the US market.

With limited knowledge of English, he went to the US and, in 1972, opened two sales offices there. Then, in 1979, the company made the courageous decision to open its own factory in Rural Hall, North Carolina, which produced mainly for the American market. North Carolina has always been most famous for textiles because most of the textile companies are located there. The subsidiary in the US was an independent operation but was still strongly embedded in the corporate strategy. The internationalization of the company called for an internationally comprehensible name and therefore the weaving mill became Lantal Textiles in $1996 .{ }^{5}$

These, and other, stories of the sample companies demonstrate that international expansion was taken very seriously and was deserving of personal attention by the company founders. Company leaders made a point to be personally present at international trade fairs and to meet with customers abroad, and it was their personal commitments that drove the international expansion of their firms. Once initial contacts were established, formal distribution networks had to be built and maintained.

\section{Relying on Distributors and Agent Networks}

It was primarily the smaller firms who relied on agents or distributors to cover their respective markets. Too small to justify sales subsidiaries, the smaller SMEs built far-reaching networks consisting of dozens of agents who also carried other, and at times competing, products to the target markets. The experiences of four smaller companies (Rüeger, DC Swiss, Sylvac, Plumettaz), all in the CHF 25 to CHF 40 million sales range, were selected to illustrate this type of distribution strategies.

Rüeger, focusing on temperature measurements in mostly industrial processes, covered the world market, except for the USA, through a network of independent agents appointed for individual markets or countries.

About 60 independent agents located in many different countries supported this sales effort. Typically, the agent handled the selling, Rüeger quoted prices for the agent who sold and

\footnotetext{
${ }^{5}$ Adapted from Lantal company profile.
} 
delivered the instruments to the customer. In the company's experience, the quality of its agent network was uneven, with only about a third earning the label excellent. Geographically, more than 80 percent of Rüeger sales were destined for the export market. Europe accounted for about 40 to 50 percent of sales, and Asia about 35 percent. Rüeger was not active on the US market due to different technical specifications. ${ }^{6}$

DC Swiss, focusing on the narrow segment of threading tools, was also using independent distributors as the backbone of its international distribution effort. However, the company augmented the agent network with a subsidiary in one key market, a logistics center for the EU, and a franchise operation in another key market. Due to its small size, it entered a collaboration with another Swiss company to serve the Chinese market.

Given the limited market opportunity of the Swiss market, DC Swiss was early in the export business. Currently, about two thirds of sales were exported. The company built up about 30 exclusive distributors, appointed per country, with some being responsible for more than one country, in total covering more than 50 countries. About 65 percent of company sales went through its distributor network, the rest direct to end users.

To strengthen its market coverage and logistics support, the company created a subsidiary in Cologne, Germany, to handle logistics to EU countries. The distribution operation in the UK was structured as a franchise. In Italy, an important market for threading tools, the company operated its own subsidiary. To help with expansion in China, DC Swiss entered into a collaboration with URMA, a Swiss producer of reaming tools, who had set up a company in China in 2008. Geographically, DC Swiss sales outside of Switzerland were largely focused on Europe, where more than 80 percent of its exports were shipped, with still smaller percentages to the rest of the world. ${ }^{7}$

Sylvac, focusing on both manual and digital measurement devices, utilized a mix of distribution channels that includes not only independent agents but also collaborations with other companies in similar circumstances. In addition, Sylvac engaged in extensive OEM arrangements for about half of its sales.

For distribution, Sylvac relied on an extensive global network of more than 60 independent agents covering most markets with substantial manufacturing industry clusters. A team of half a dozen technical sales representatives maintained connections to the agents. In two European markets, France and Germany, Sylvac collaborated with Trimos SA and owned part of the distribution operations. The China operation and OEM sales from there were fully owned by Sylvac. The vast majority of Sylvac sales were exported. European markets accounted for about half of sales, the US about 15 percent, Asia-Pacific about 20 percent and 15 percent were accounted for by many other smaller markets. ${ }^{8}$

\footnotetext{
${ }^{6}$ Adapted from Rüeger company profile.

${ }^{7}$ Adapted from DC Swiss company profile.

${ }^{8}$ Adapted from Sylvac company profile.
} 
Plumettaz, a manufacturer of cabling equipment, also maintained an extensive agent network but had augmented it by selective subsidiaries that also engaged in some production or assembly.

Global sales at Plumettaz were made through four international sales subsidiaries in the Netherlands, Singapore, China and, most recently, in the US. The company also maintained some 50 distributors across the world. A small number of international sales managers kept close contacts with key clients and supported agents from the company base in Switzerland. ${ }^{9}$

Maintaining global market coverage through agents was generally viewed as challenging. The quality of the agent networks was not uniformly high, and control over the distribution channel was less effective than it would be with a network of wholly owned subsidiaries. Despite these difficulties, it is nevertheless impressive how small firms with limited resources can deploy globally. None of these companies would have survived if they had not extended their geographic coverage given that they were focused on very narrow market niches.

Agent or independent distributor networks were not only the choice for smaller companies, but also common among companies starting out and, in some cases, remained the main sales network even after the company had grown. Caran d'Ache, producers of fine writing instruments, which are distributed globally, exemplifies a company that has adhered to its traditional network over a long period of time.

At Caran d'Ache distribution in international markets was made through a few selective subsidiaries in Japan, Germany and France. The vast majority of the 90 markets were served through independent distributors. Some of these distributors had been working with Caran d'Ache for generations and were selected and appointed partly on the basis of their fit with the Caran d'Ache philosophy. Shipments were made from the Swiss base within 48 hours of order and all invoicing took place in Swiss Francs. To build more sales abroad, the company engaged in shop-in-shop sales, as well as in duty free zones at airports. In China, the company collaborated with a partner around an art center concept. ${ }^{10}$

\section{Building Distribution Partnerships}

The task of finding and appointing suitable distributors or agents takes time. Some companies have tried to use partnerships as a means to arrive at quick market coverage. This process invariably requires relying on other, larger firms, who can cover multiple markets and thus offer instant distribution to an SME. As we can see from the examples of Medartis and LNS, the OEM distribution arrangement can lead to conflicts of interest between the exporting SME and the OEM companies that are expected to provide the sales arm.

\footnotetext{
${ }^{9}$ Adapted from Plumettaz company profile.

${ }^{10}$ Adapted from Caran d'Ache company profile.
} 
When Medartis first went to market (in 1997), the company tried to leverage its connections to the Straumann Dental company using the Straumann distribution system. Medartis quickly realized that this did not work and began to build its own distribution system based on sales subsidiaries and distributors not related to Straumann Dental. International expansion began in 2002 with the opening of sales offices in Germany, Austria and France. A number of sales subsidiaries followed in the UK (2003), the US (2004), Mexico and Poland (2008), as well as in Australia and Spain (2010). The most recent sales subsidiaries were formed in 2018 through the acquisition of a local distributor in Brazil and a new operation in Japan. In addition to its 11 sales subsidiaries employing about half of Medartis staff, Medartis products were also sold in 40 countries through 35 distribution partners, collectively accounting for about 15 percent of sales. ${ }^{11}$

Medartis needed access to orthopedic surgeons and was not well served by the Straumann Dental distribution network which was geared toward dental surgeons. This experience demonstrates that the best distribution network needs to reach the exact and specific sales targets. No matter how willing, a partner who is not already serving those targets is not likely to provide a strong sales effort, because that partner would need to learn a different "language" and visit targets not already on its customary visiting lists.

That partnerships with OEMs visiting the required target companies are not a guarantee for success was experienced by LNS, manufacturer of bar feeding equipment.

LNS bar feeders were not stand-alone equipment. Instead, they were engineered to be plugcompatible with a range of OEM machine tool manufacturers, such as for lathes. Leveraging the connection, LNS first sold through the machine tool OEMs, making them sole agents. This did not work in France or in the US market as there was a conflict of interest between OEMs and equipment dealers. OEMs did not like the fact that LNS bar feeders would fit with any equipment, not just their own. While an OEM machining center might sell for CHF 250,000, a bar feeder sold on average for CHF 25,000. For dealers, on the other hand, these were peripherals, offering them extra income at even better profitability than selling OEM machines. Eventually, LNS switched its sales strategy to go directly to dealers, eliminating OEMs. To support sales into international markets, LNS began to create its own sales network to better control its markets. The entry into Japan was in 1978 and the US sales network was created in 1982. As international sales developed, a need for company branches arose, starting in 1984 in Los Angeles (US), followed by France and Italy in 1990, the UK (1992), Malaysia (1994) and Korea (1999). ${ }^{12}$

LNS demonstrates that a prime reason for moving to one's own sales network was control over its sales effort. Control is maximized through a salesforce in the company's employ. This is, of course, very difficult to reach for small firms which, at best, can employ regional managers who stay in touch with the distributor network, but this does not assure control down to the customer contact level.

Felco, the producer of agricultural cutting tools, leveraged a partnership with a large international firm to expand its own distribution coverage.

\footnotetext{
${ }^{11}$ Adapted from Medartis company profile.

${ }^{12}$ Adapted from LNS company profile.
} 
In 2014, Felco entered a wide-ranging partnership with Stihl of Germany, world leader in power saws and lawn care machinery. Stihl, who was into cutting big trees, wanted access to Felco technologies and products for the cutting of small trees and branches. Felco agreed to a partnership that offered important benefits for both companies. Stihl obtained access to Felco's various technologies on an OEM basis and, in return, Felco obtained access for its tools through Stihl's 40,000 points of sales, worldwide. The products marketed through Stihl were being co-branded but produced by Felco. ${ }^{13}$

As seen from the experience of companies starting out with either independent distributors or agent networks, or having relied on OEMs, the preferred channel in the end is a fully controlled network consisting of sales subsidiaries. The next section will explore how this was accomplished by some of the firms in the research sample.

\section{Creating Subsidiary Networks}

The histories of many SMEs in this book confirm that although starting out with agents, wholly owned subsidiaries came later, replacing independent distributors in key markets. This development took some time and companies with that construct tended to have sales above CHF 100 million. These companies were able to cover the world market, or their relevant part of it, deploying around a dozen sales subsidiaries in their key markets. In most instances, no more than 15 subsidiaries, based worldwide, sufficed in being present in $75-80 \%$ of the market a company served.

Ricola, the herbal candy producer, began to export in the early 1940s to Germany and France. Relying on international distributors at the early stage allowed Ricola to concentrate on production, leaving local distribution, marketing, and selling to external partners, one country at a time. The network included over 50 distribution partners worldwide.

Those distributors were important to Ricola because in the early growth phase of the firm production was a constant constraint. Relying on distribution partners who took responsibility for distribution in their countries, allowed Ricola to focus on its production bottleneck. In the 1960s, the major export markets were France and Germany. In those countries, and in Switzerland, Ricola became the market leader in its category. In the 1970s, Ricola initiated considerable marketing activities in Japan, Hongkong, Taiwan and Singapore. In 1980, the subsidiary Ricola US took up operations but the company had already been present in the American market since the 1960s. In China, Ricola's presence goes back about 30 years with a strong track record and its brand well-known there. Ricola was exporting 90 percent of its production and converted a number of local operations into subsidiaries, seven in total, mainly in the US, Germany, France, Italy, UK, Canada and Italy. Major changes also took place in the Chinese markets where the company changed its initial long-running export relationship with a Swiss-based trading company to deal directly with a Chinese partner. This resulted in a substantial expansion of its point-of-sale (POS) across all regions of China. ${ }^{14}$

\footnotetext{
${ }^{13}$ Adapted from Felco company profile.

${ }^{14}$ Adapted from Ricola company profile.
} 
Jura Espresso Machines went through a similar transformation of its distribution network. As its marketing strategy, under the "House of Jura" brand, required that Jura coffee machines were not placed next to those of any other competitor, stricter control over its distribution network became a key element of the company's strategy.

For Jura, the company did not want to be placed as one among 20 other coffee machine brands, just anywhere on a retailer's shelf. To avoid this, the company engaged a strict control of the POS environment, from controlling dealer needs, controlling how customers were to be treated and teaching how to sell the Jura line. This focus, Jura believed, could only be achieved with a single line of espresso machines on display. Jura had thus reduced the number of selling points globally from 11,000 POS at one time to presently only about 7,000 POS. At the same time, efficiency per POS substantially increased. Global distribution was achieved by a combination of company-owned sales subsidiaries in key markets in Europe, North America and Asia, combined with national dealerships selling through retailers. Although distributor sales accounted for only about 30 percent of global Jura sales, this segment experienced the fastest growth. ${ }^{15}$

Even for a company such as Jura, a complete reliance on sales subsidiaries for all markets was not considered. With the economic development of some of the markets still being served by distributors, it was likely that some of those would eventually be converted into sales subsidiaries.

The strategies pursued by two electronic component companies, LEM and u-blox, who started to build their networks over the past 20 or 30 years, show that companies continue to employ a mix of distribution forms, combining companyowned distribution with agents or catalog businesses.

At u-blox, sales to OEM customers were in the hands of three crews with regional concentration on Europe, North America and Asia/Pacific. These teams could count on the support of 13 sales offices and about 50 distributors in key countries. The opening of international sales offices started early with u-blox opening US and Asia offices in 2001. In 2018, sales were about evenly divided between Asia/Pacific (35 percent), Europe/EMEA with 32 percent and the Americas with 32 percent. $^{16}$

According to LEM's business model, the company aimed at going direct to countries or markets, accumulating annual sales CHF 4 million or more. At that level, LEM was able to justify establishing a sales subsidiary. Below that threshold, the company was selling through distributors and catalogs. The need to be close to customers led to the establishment of more than 20 sales offices across the world. ${ }^{17}$

With sales ranging between CHF 300 million and CHF 400 million, both LEM and u-blox were in a much better position to field their own distribution and sales

\footnotetext{
${ }^{15}$ Adapted from Jura company profile.

${ }^{16}$ Adapted from u-blox company profile.

${ }^{17}$ Adapted from LEM company profile.
} 
forces. The same was true for other companies in this research, for example, Komax, maxon, and Oetiker.

\section{Market Entries Around Manufacturing Acquisitions}

At some companies, the buildup of international distribution networks went hand in hand with the acquisition of foreign companies and their operations. Once a company with manufacturing operations abroad was acquired, the SME usually obtained market access, base sales, and distribution outposts around the newly acquired operation.

Two companies can serve as examples here-Filtrox and Bachem-which used an acquisition strategy to build, among other things, a sales network. The creation of production capacities will be discussed later when looking at the manufacturing footprint of the researched companies.

In 1984, Toni Rusch became managing director of Filtrox. His prior experience was in the chemical industry where he developed a strong international orientation. Filtrox was still relatively small. With exports important, Filtrox had only a single production site in Switzerland and no foreign subsidiaries. Rusch fostered the international expansion and, in the following years, whenever an opportunity arose, Filtrox took over smaller competitors and eventually become number two in the global market. In 1988, Filtrox acquired the UK company Carlson Filtration with around 60 employees. Carlson had a strong position in England and in the Commonwealth countries, where Filtrox had not been very active before. With a market share of over 50 percent, Filtrox became world leader in beer filtration. In 1998, Filtrox started a joint venture (JV) with a Czech company to produce filter sheets in Broumov, CZ. In 2001, it acquired another competitor, Papelera del Besos Placas Filtrantes S.L. in Barcelona, which had a good market position in Southern Europe. Finally, in 2013, it acquired the majority stake in Columbia Filter, in Mexico, to gain a better position in the North and South American markets. ${ }^{18}$

The Filtrox experience and development demonstrates how each acquisition, in the UK, the Czech Republic, Spain, and Mexico, provided market entry to specific regions or market segments and were the primary reasons to acquire these international firms.

Throughout its expansion, Bachem made several acquisitions that added to its global footprint. Most of the acquisitions were initiated by the companies approaching Bachem and offering themselves for sale, reflecting more of an opportunistic rather than a planned approach. Each piece of the puzzle was then integrated into the overall Bachem operation to expand its global sales footprint. Bachem began exporting early. Sales and marketing centers were first opened in Germany (1988) and in France (1993). The market entry into the US market had previously taken place with the opening of a subsidiary in Philadelphia. Up to that point, manufacturing had taken place only in Switzerland.

\footnotetext{
${ }^{18}$ Adapted from Filtrox company profile.
} 
The first major acquisition came in 1996 when Bachem AG was able to acquire Bachem, Inc., located in Torrance, California. Bachem, Inc. was originally established in 1971 by Bachem's founder together with a local partner. The two separated over a business disagreement after one year, turning the US company into becoming Bachem AG's major global competitor. When the original partner wanted to sell, Bachem used the opportunity to acquire the entire operation in 1996 and integrate it into its own business, thus creating Bachem Americas, Inc. With the acquisition came also subsidiaries in Germany and in the UK. In 1999, Bachem was approached to acquire Peninsula Laboratories, also located in California. The company marketed different peptides, largely focused on immunology applications, which represented a new field for the company. After lack of success, Peninsula was prepared to sell and Bachem acted on this opportunity. Included in this acquisition was a subsidiary in the UK which was later integrated with the earlier operation acquired from Bachem, Inc., into a single Bachem (UK) Ltd. in St. Helens.

The series of acquisitions in the US during the period of 1997 to 1999 led to a realignment of marketing and sales operations in the United States with focus on two locations in California. Marketing and distribution operations for North America were managed through the Torrance unit. Sales to Japanese customers and to customers in China, Taiwan, Korea and other Asian countries were the responsibility of a unit recently (2018) opened in Japan. For some countries, Bachem signed distribution agreements with firms who stocked standard or catalog products. ${ }^{19}$

The positive experience with the integration of the acquired operations triggered a similar move in Europe where Bachem, in succession, first consolidated its UK units into a single operation and then moved the German operations from Heidelberg to Weil a.R. (on the Swiss/German border outside of Basel), while at the same time merging its French marketing operation into a single European distribution center in Weil. Marketing and sales responsibility for Europe, India, and the Near East remained in the company's head office location in Switzerland.

\section{Cracking Difficult Markets}

Many companies confirmed that entry into the Japanese market posed difficult challenges. It required perseverance and a special effort. EAO, who managed to establish its presence in the Japanese railroad market, gained an $80 \%$ market share for door opening push buttons as a result of custom solutions and an extremely high delivery responsiveness. ${ }^{20}$

The example of LNS demonstrates that sometimes several attempts were necessary to successfully enter Japan. It required three attempts by LNS to successfully establish itself in the country.

Japan had long been an important market for LNS, but it took three attempts until LNS could finally establish a firm foothold. Japan was a market with a large number of installed CNC machines and lathes, all prospective 'customers' for bar feeders, served by local suppliers. In

\footnotetext{
${ }^{19}$ Adapted from Bachem company profile.

${ }^{20}$ See EAO company profile.
} 
its first attempt, LNS started by appointing a large Japanese trading company, specializing in all types of machine tools, as its agent. When results were disappointing, the Japanese agent suggested to form a JV. LNS founded Nippon LNS in 1991 as a JV, but results still disappointed in relation to the potential of the Japanese market. The breakthrough finally occurred in 2012 when LNS could acquire a Japanese company. Yoshida Tekko KK had been founded in 1981 and its owner wanted to retire. With more than 100 employees, the company specialized in producing chip collection and air filtration systems, two areas with a perfect strategic fit for LNS. Yoshida continued to serve its markets with its own systems, plus selling LNS bar feeders, which were sold to the same customer group. As an extra bonus, LNS was able to transfer Yoshida's advanced filtration systems to be produced in markets outside of Asia. ${ }^{21}$

A different route was chosen by maxon, which early in its development came to the attention of a major Japanese company. This contact, established at an industrial fair, eventually led to a key order that helped launch maxon in Japan.

At the 1970 Hannover Fair, maxon made contact with the Japanese firm Cannon which led to a visit by Cannon executives to the maxon operation in Switzerland. Long negotiations ensued and eventually Canon took out a license for maxon Motors which gave maxon an early entry into the Japanese market. In 1979, the relationship with Cannon resulted in a major order over CHF 8 mio for motors to be used in a tachometer instrument. The licensing agreement with Canon expired at the end of 1987 when maxon wished to market its products directly. The agreement had favored large volumes, whereas maxon preferred smaller volumes of specialized motors combined with a flexibility to react rapidly to changing customer requirements. $^{22}$

The US market also posed challenges for entry into some segments. Acutronic, one of the smaller companies in the research sample, needed to find a way to enter the US market, a must-win market for its product lines of simulators. In the end, only after Acutronic had established a formal base was it possible to participate in that key market.

Acutronic USA was founded in 1989 in Pittsburgh, PA. Because of the importance of the US Aerospace and Defense (A\&D) industry, it was essential to be active in that market. However, due to US regulations regarding confidentiality in the A\&D industry, the Swiss and US entities had always been separate from each other. Hence, development and construction existed at both locations and worked independently from each other. While these duplicate structures made no sense economically, they were necessary and meaningful from a political perspective. Acutronic USA was staffed only with US citizens, not even the Swiss flag was flown in front of the Pittsburgh office. Customers typically did not know that Acutronic USA was owned by a Swiss company and considered it a US business. Through the US entity, Acutronic was able to serve all the important customers within the US A\&D industry. ${ }^{23}$

\footnotetext{
${ }^{21}$ Adapted from LNS company profile.

${ }^{22}$ Adapted from maxon company profile.

${ }^{23}$ Adapted from Acutronic company profile.
} 
Entering China also presented many firms with particular challenges. Two strategies, different in intent, can be discerned. One set of companies used China as a workbench to source products or materials. Those strategies will be further discussed in the section about Sourcing. A second set of strategies dealt with entering China as a market. Many companies have achieved significant market presence in China by establishing local sales offices. The experience of Plaston combines both challenges, China as a workbench and as a market.

When In 1994, Hilti, a major customer of Plaston, disclosed plans to establish a production facility in China, requiring Plaston cases to be produced there, the Plaston management decided to take up the challenge. Within a year, case production was installed in a local stateowned enterprise. However, operation at the newly established Plaston Zhanjiang Ltd did not proceed smoothly. Plaston faced numerous challenges in dealing with government regulations, power outages and staffing requirements set by the state-owned business. At times, it took ten people to produce a single case. After just three years, the decision was made to close Plaston Zhanjiang Ltd.

This first venture into the Chinese market cost Plaston dearly but it also provided the company with an invaluable experience. After this false start, Plaston did not give up its ambition to gain a foothold in China. A breakthrough came in 2004 with the construction of a wholly owned production facility in Jiaxing near Shanghai. The production manager of the Plaston factory in Widnau, Switzerland, moved to Jiaxing to become the new plant manager there. $^{24}$

\section{Managing Changes in the Distribution Channel}

Distribution channels can be subject to changes due to technology and competition. Even the best laid distribution schemes can become obsolete and will force companies to respond, regroup, and rebuild.

A case in point is Fraisa, manufacturer of metal cutting tools. Its sales and distribution were initially centered on Switzerland. Exports were handled through dealers and distributors who carried a large number of different tools in their assigned territories. Fraisa did not engage in any direct sales. These tool distributors, or agents, were all resellers of a full range of tools, including those of other manufacturers. All through the 1980s, Fraisa built up an extensive international network of resellers.

A first change in Fraisa's distribution model was prompted by the bankruptcy of its dealer in Lyon, France. Fraisa, to avoid a loss of CHF 300,000, took over the Lyon dealer in 1984. With this first foreign subsidiary direct customer support was now provided in France. Then, at the beginning of the new century, the market for cutting tools had changed fundamentally compared to the 1990s. On the one hand, big distributors started to bring lower priced private label tools to the European and the US markets, mainly copies of other tools, but produced at significantly lower costs in Asia! On the other hand, real global companies were arising, partially by organic growth but to a large extent by acquisition, the biggest of them being the

\footnotetext{
${ }^{24}$ Adapted from Plaston profile.
} 
Swedish Sandvik group. Others included the SECO group and the German Walter Group. From then on it was no longer a business of millions but of billions instead.

Fraisa took another step in 1988 with the foundation of Fraisa Deutschland $\mathrm{GmbH}$, taking over a small distribution company with an attached workshop for special tools and the re-sharpening of cutting tools. The Italian subsidiary was founded in 1992. As trade barriers started to be reduced and Fraisa European competitors started to enter Switzerland, expansion into European markets became a necessity. As a result, Fraisa found itself suddenly confronted with low-priced Asian products imported into its own customary markets and no entry barriers to contain this trend. With its reseller-model in danger, the company was looking to defend its business in ways that could not be easily copied by, or sourced from, Asian products. Sales of Fraisa tools now took place worldwide through multiple channels: the company-owned sales units in Switzerland (including Asia and South America), in Germany, Hungary, Italy, France (Benelux and Iberia), the US (North American region) and China (for China and Taiwan). In addition, sales and support services were rendered through a network of independent dealers across a large number of countries. ${ }^{25}$

The Fraisa experience proves that unexpected developments can wreck the best laid distribution plans, forcing companies to jettison long-cherished arrangements and quickly open new channels. Failing to do so can clearly risk the business.

\section{Reflections}

The practices described in this chapter were not always of the SMEs' own choosing. While control over distribution channels allowed for close management of the messaging targeted at the customer, as the case for Jura, smaller companies (e.g., DC Swiss) were not in a position to do this because their sales per country, or market, were too low and did not cross the threshold to make such a control economically viable. Companies making tools, or consumables, that were widely dispersed across many different user industries, did not easily reach critical mass necessary for fielding country-specific and fully-owned distribution.

Companies with higher sales per country were able to articulate their own distribution and sales strategies, indicating that clear thresholds exist when a companyowned sales unit could be implemented (LEM). In contrast, those firms selling major equipment with higher sale amounts per deal were more likely to field direct sales (see LNS or Pilatus).

Also noticeable are the geographic patterns observed in the international expansion of the firms. While most companies expanded to other European countries first, there was a different pattern seen among older companies, who made their first overseas jump to North America (see Sefar), compared to companies founded more recently, which tended to favor Asia, and China in particular, for expansion at a relatively early stage in their development (Sylvac). This shift in prioritizing Asia over North America reflects the geopolitical and economic shift in the global economy over the past decades.

\footnotetext{
${ }^{25}$ Adapted from the Fraisa company profile.
} 
Open Access This chapter is licensed under the terms of the Creative Commons Attribution 4.0 International License (http://creativecommons.org/licenses/by/4.0/), which permits use, sharing, adaptation, distribution and reproduction in any medium or format, as long as you give appropriate credit to the original author(s) and the source, provide a link to the Creative Commons license and indicate if changes were made.

The images or other third party material in this chapter are included in the chapter's Creative Commons license, unless indicated otherwise in a credit line to the material. If material is not included in the chapter's Creative Commons license and your intended use is not permitted by statutory regulation or exceeds the permitted use, you will need to obtain permission directly from the copyright holder.

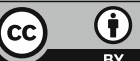

